\title{
The Construction of Self and the Rejection of the Natives as the Inferior Other: Sadegh Hedayat's Blind Owl
}

\author{
Khalil Mahmoodi \\ School of Language Studies and Linguistics, Faculty of Social Sciences and Humanities \\ Universiti Kebangsaan MalaysianＥ-mail:Khalil.mahmoodi@gmail.com \\ Dr. Shanthini Pillai \\ Dr. Raihanah M M \\ Esmail Zeiny Jelodar
}

Received: March 17, 2011 Accepted: April 8, 2011 doi:10.5539/ells.v1n1p80

\begin{abstract}
Iranian intellectuals including Iranian modern literary writers who were supposed to act as the consciousness and voice of their people fall prey to the imported Western modernity. The influence of these western education and culture rendered them so alienated that pushed them to build a big rift between themselves and the rest of the society. This causes these writers to create an image of the natives that comes to the fore as the most macabre and stereotypical representation of the indigenous people. Although many different studies have been carried out on the Blind $\mathrm{Owl}$, it seems that little focus has been cast upon the major reasons of such presentation. This paper explores the text to reveal how the author, by giving credit to himself as an 'I', artist and a painter, struggles to build a rift between himself and the others, the rest of the society, the world of Rajaleha, the Rabbles. This study, by focusing on the representation of the native as the other, attempts to disclose the orientalised system of representation that the author has employed to portray the majority of the society as the peripheral and finally as the 'Other'.
\end{abstract}

Keywords: Rajaleh, Lakateh, Ethereal Girl, Other, Self, Colonial Discourse

\section{Introduction}

Notwithstanding the fact that Iran is having a long and a complicated procedure, its design is structured by the rise and the fall of sequential dynasties - with intervals of chaos and confusion. In the 6th century BC Cyrus the Great established the Persian Empire, which was invaded and demolished in 330 BC by Alexander the Great. In the following centuries, Iran was attacked by the Parthians, the Arabs, the Mongols and different Turkish dynasties.

After the victory and dominance of the Arab in the middle of the 7th century, the ancient Persian religion of Zoroastrianism began to be replaced by Islam. The Seljuk Turks arrived in the 11th century, and the Mongols invaded and overrun Iran under Genghis Khan and his grandson Hulagu Khan in the 13th century and Tamerlane (Timur) in the 14th century. Another Turkish dynasty, the Safavids, brought Iran under their control in the 16th century which was overthrown only by yet another Turkish tribe, the Qajar, in the 18th century. Literacy was fearfully low, something on the order of two or three percent, and substantial portion of the population was pastoral nomads and most of the urban residence were mostly uneducated and extremely traditional and religious.

In 18th-19th centuries Iran falls under the increasing pressure of European nations, particularly the Russian Empire and the Great Britain. According to 1907 treaty Iran was actually divided into the territorial penetration of Russia and Britain (Katem, 2006, p. 201). After the Iran-Russia wars of 1813 and 1828, and the unequal Treaty of Paris (1857), Iran lost its independence (Katem, 2006, p. 227). "The transformation of Iran from an independent and cohesive Asian state into a "buffer state" was mainly due to the colonial penetration and rivalry between Great Britain and Tsarist Russia" (Benab, 2011, p. 1). The presence of the West in Iran and the dispatching of the Iranian students to Europe, especially England and France rendered a huge social and mental transformation not only in the returnees from Europe but also in the social life style. The return of these students from Europe was associated with the emergence of a new trend of European thought and life style Called modernism which was in the opposition of the traditional culture and whatever considered as traditional, including the public religion of people, Islam (Axworthy, 2007). The new Iranian educated people who were carrying the title of monavarol-feker "enlightened thinker" began a new era in the history of the country, with no clear notion of what modernity is and how to apply it in a traditional country like Iran. These intellectuals who have at this stage found themselves left behind the European countries began to blame the Arab, Turk and Mongol and the other races as the main cause of their backwardness. Driven by his/ 
her intellectuality and a very human and natural desire to push forward, s/he is attracted to the culture and civilization which had developed in the West. All due to the superiority of the colonial ideology they began to define the native people as savage, backward, and underdeveloped. Consequently these westerly educated people began to feel that they have been captivated in a society which does not fit them at all and this way they established a big rift between themselves and other people.

\section{Blind Owl: a Summary}

The novel is into two parts which are formally connected by a few passages at the end of part I and at the end of part II. Part I begins when the narrator, a pen-box illustrator, is visited by an uncle from India he has never seen. In order to offer him some refreshments, he goes to bring the jug of wine on the recess when suddenly sees, through the crevice of the wall, the scene of the single and compulsive subject of all his illustrations. She is an extremely beautiful and exotic woman with an unconscious smile on her face and he falls deeply in love with 'the ethereal woman', 'this girl, no, this angle' (Hedayat, 1984, p. 10). He embarks on a journey in search of the ethereal girl. He becomes convinced that she was not of this world, and she would 'wilt at the look of a stranger, an ordinary person' (Hedayat, 1984, p. 11). But upon returning he finds the girl sitting on the doorsteps. The mysterious girl enters his room and lie in his bed. He gently pours a cup of the wine which he inherited from his mother in which there was the poison of nag, the Indian serpent through her locked teeth into her mouth. This leads to the death of the ethereal girl (Nafisi, 2003, pp. 654-655). He dismembered her and buries her in a nearby small town on the site of the ancient city of Ray. In the second part of the story, after smoking a lot of opium, the narrator wakes up in a world which is very close to his real world and he recounts his mental and physical decline following his marriage to a woman who refuses to have sex with him but has countless lovers. He kills her.

\section{Binary Opposition}

The construction of self fundamentally stems from difference, mostly from rejection of Others. In this case, one postulates a simple binary opposition between self, a pure and original and Others, as inferior and physically and mentally contaminated creatures, as a means of demonstrating the 'I'. Here, the Self is envisaged as undivided, as possessed of an original authenticity that the Others lack (Cole 1995: 1). Self is in fact constructed by difference, contrast and finally rejection or suppressing the Other as the component of Self. This unitary conception of Self also tends to blame any weakness or inferiority within the Self on an Other. The story is built on the basis of binary opposition. Good in the opposite of bad, Islamic society in the opposite of European society, Platonic or better to say pure unpolluted Sassanid love against contemporary, Islamized love, Ethereal girl in the opposite of Lakateh, The narrator against the Rajaleha, old Rey representing Iranian historical glorious era in the opposite of post-Islamized or the contemporary time, to mention just a few. According to Ashcroft (2004, p.23) "binarism comes from 'binary', meaning a combination of two things, a pair, 'two', duality (OED). The binary opposition is the most extreme form of difference possible. Such oppositions, each of which represents a binary system, are very common in the cultural construction of reality."

Binarism comes from 'binary', meaning a combination of two things, a pair, 'two', duality $(O E D)$, this is a widely used term with distinctive meanings in several fields and one that has had particular sets of meanings in post-colonial theory. The binary opposition is the most extreme form of difference possible - sun/moon; man/woman; birth/death; black/white. Such oppositions, each of which represents a binary system, are very common in the cultural construction of reality (Ashcroft, 2004, p. 23).

Binary oppositions are structurally connected with one another, and in colonial discourse there may be a degree of diversity of the one underlying binary - colonizer/colonized - that becomes reemphasised and re-expressed in any particular text in many different ways (Ashchroft et al, 2004, p. 23). The binary opposition is the most extreme form of difference possible through which the system of the cultural construction of reality works. Through binary oppositions as the basic dichotomies which advocated in the West, what Western thought is generally concerned is to see the world in terms of the Westerners against non-European origins, i.e. the Other. This binary system establishes a relation of dominance and justifies "the hierarchical cultural and radical assumptions of European thought" (Royle, 2000, p. 190). The binary system plays a very significant role in "constructing ideological meanings in general and extremely useful in imperial ideology" (Ashcroft et al, 2004, pp. 23).

\section{Narrator/ Rajaleha oppositions and Self Alienation}

Al-e Ahmad (1984, p. 57) asserts that a person who is mentally westoxificated is a person or more precisely an intellectual who has severed his ties with the essence of society, culture, and custom. He is not a bond between antiquity and modernity. He is not a dividing line between the old and the new. He is something unrelated to the past and someone with no understanding of the future. He is not a point on a line, but an imaginary point on a plane or in space----just like that dust particle. Al-e Ahmad's emphasis is on the Westoxicated creature's disinterest in his/her own culture, society, and community, such a creature is not entirely uprooted from his/her community, she/he is not 
separated from her/his means of communication and language. She/he is just infactuated and fascinated by an alien culture and society. The more pronounced this infatuation becomes, the more s/he becomes, in Al-e Ahmad's view, alienated from her/his own community.

In the Blind Owl, there is a sense of anger dominating the whole story. The narrator feels that the world in which he has been caught is not constructed for a person like him. "For some reason all activity, all happiness on the part of other people made me feel like vomiting. I was aware that my own life was finished and was slowly and painfully guttering out" (Hedayat 1957, p. 60), and immediately asserts that there is no relationship exist between the lives of the people around whom he labelled as fools and him whom he had already identified as an artist, "What earthly reason had I to concern myself with the lives of the fools, the rabble-people who were fit and healthy, ate well, slept well, and copulated well and who had never experienced a particle of my sufferings or felt the wings of death every minute brushing against their faces ?" (Hedayat 1957, p. 60). The narrator finds himself in a horrible way decomposing, identifies that he is alive, a living being who has a dreadful life. "I was slowly decomposing while I yet lived. My heart had always been at odds not only with my body but with my mind, and there was absolutely no compatibility between them. I had always been in a state of decomposition and gradual disintegration" (Hedayat 1957, p. 53).

According to Mirabedini (2003, p.791) such an "individual who has a half European characteristic and half native features," in other words composed of two contradictory derives is looking for a truth which he has become acquainted with in Europe, "A thought which I found intolerably painful was this: whereas I felt that I was far removed from all the people whom I saw and among whom I lived, yet at the same time I was related to them by an external similarity which was both remote and close" (Hedayay, 1957, p. 53). Thus when he comes to his native homeland he feels that "everything related to the life-style and the joys of others nauseated him" (Hedayat, 1984, p. 37). This sense of anger will cause to establish impenetrable wall between himself and others. He realises that "a frightful chasm lies between others and him" (Hedayat, 1984, p. 2). He finds himself lonely and everyday this isolation becomes stronger. When he reaches where it is supposed to be the secure space of his self-realization, he faces a bunch of what he calls superstitious gossipy and whores and he transcribes all these observations onto the paper and he realises that that there is no more any place for the poetry, his feelings or thoughts. At this time he depicts himself as the self who is enchained in such a trashcan full of worms and dirt that he has no choice but to escape, but there is no loophole. The Rajalha, the rabbles have occupied everywhere, they build chains with their polluted hands and place them before the feet of such a rare person (Etehad, 2009, p. 186). This is the mode that the modern education and upbringing have induced in many of Iranian intellectuals, especially in those who had been fascinated by the Western literature, thoughts and customs, and "Sadegh Hedayat was one of them" (Safa, 2003, p. 187, qtd in Ethad).

\section{The Negative Pictorial Manifestation of the Natives as the Other}

The narrator, the protagonist, who is the inevitable outcome of the cultural and political upheavals and mental and cultural transformation of a society has been afflicted by the western education and culture which clearly manifested in his artistic skill that he has brought with himself from the West, he develops a sense of humiliation toward his own traditions and native people and this makes the narrator to reveal society as distastefully sluggish and inactive filled with people who do not resemble him in thoughts and manners. Thus in order to define and give meaning to himself as an 'I', he creates a discourse mostly oriented from his ideological and Westerly educational standpoint. As an avant-garde artist who was supposed to push the boundaries of what is accepted as the status quo, traditional literature, religion and traditions of people, Hedayat draws a line from the onset between himself and those who are different from him in thoughts and behaviours.

This Oriental discourse puts face and a mould to the Oriental character [the natives, rajaleha, the rabbles, the Lakateh, the whore, and all the others]. This way the ideas about it influence the idea of the West and the other. In many ways this notion of the superior West and the inferior East is solidified because the difference between them is intensified by the Orientalist discourse (Said, 1978, p. 42). Discourse is governed by the ruling power; the ruling power determines what is to be narrated and how to narrate an event. In the case of the Blind Owl, the narrator of the story appropriates this authority to represent the natives the way he likes. Said $(1978$, p. 20) argues that an Orientalist writer must first of all locate himself or herself vis-à-vis the Orient. This will later on affect his/her interpretation of the Orient.

One of the famous themes in the Hedayat's works is the description and the judgments that he extends to the people whom he names rajaleha, the rabbles. By the word rajaleha, he does not mean hooligans, thugs and hoodlum in its ordinary sense, but all the people who in most cases do not believe in the values that they pretend to have been attached. In order to gain success in the life they will not avoid any activities including begging, embezzlement, lying, vulgarity, deception, fashion follower or to be an opportunist. In the Dark House (1995), the isolated person 
tells the narrator "Only a bunch of thieves, shameless fools and sick people are allowed to live in this environment. Those unfit for thieving or baseness and those not given to flattery are pronounced 'unfit for living!" (Hedayat, 1995, p. 40). In the story of Deadlock (1942), the protagonist has fallen behind of his cheeky and thief colleagues because of his honesty and sincerity. When he returns to his hometown from Tehran, everything appears to him narrow, limited, ordinary and low and "his work pals had pushed their grip further into the abdomen of life...some of them more or less had reached their limited aspirations: their belly had been grown bigger and their sexual passions had been transmitted from their waist down to their jaws, or in the distresses of life, they had focused on the swindling, plundering of their peasantry, cotton, opium and wheat products or their children's dippers and their old gout" (Hedayat, 1942, pp. 42-43).

In another story named Gojaste Dej which according to Homa Katouzian (1993, p. 54) does not belong to Hedayat's Psycho-fiction stories- we read that "you mean these people?...what controls them is firstly the belly and secondly their sexual passion, with a bundle of anger and bundle of must and must not which are blindly infiltrated into their ears" (Hedayat, 1932, p. 249). In the Three Bloods (1932), we witness some traces of the rajaleha, the rabbles, in the male cat. When in the spring season, Nazi-Siyavash's female cat- emitted sorrowful moan of love: "Male cats from all around the neighbourhood heard Nazi's moans and came to meet her. After much struggle and many cat fights, eventually, $\mathrm{Nazi}$ chose the strongest and the most boisterous of the suitors to be her mate. Of prime importance in love making is the animals' special scent. That is why males that are tame and clean do not move their females. While alley cats, cats on the prowl, thieving cats, emaciated cats, stray cats, and famished cats; in general those cats whose hides have retained their primordial scent, attract the females most" (Hedayat, 2000, p. 5).

But in the Blind Owl, the description and making judgments on the rajaleha is more detailed, much bitter, much clearer and much harsher than any other Hedayat's works. The point that Hedayat does not mean the hooligans, thugs and hoodlum in the street by the word rjaleha is more observable in the novelette. Among these rajaleha, who are from every profession and social groups; a trip-peddler, a jurist, a liver-peddler, the chief magistrate, a judge, a trader and a philosopher are some who have relationship with the Lakateh, the whore, the narrator's wife. In one stage, the narrator tries to learn their manners and ethics with the hope to attract the whore, but he says "How could I learn the ways of the rabble anyway? But now I know that she loved them because they were shameless, smelly fools" (Hedayat, 1984, p. 29). He says that not only is he not afraid of the death but also longs for it, but "I was afraid, however, that the particles of my body might blend with those of the rabbles, an idea which I could not bear" (Hedayat, 1984, p. 45). He earnestly wished to die but he was frightened that such a thing happens to him: "Sometimes I wished that I had long hands and long sensitive fingers so that I could gather the particles of my body carefully and prevent them from getting mixed with those of the rabbles" (Hedayat, 1984, p. 45). The narrator describes these people this way when he talks about what he did to disappear and lose himself and escapes from all these miseries and affliction that enmeshed him "I passed through many streets and distraughtly walked by the rabble who, with greedy faces, were in pursuit of money and last. In fact, I did not need to see them to know them; one was enough to represent the rest. They were all like one big mouth leading to a wad of guts, terminating in a sexual organ" (Hedayat, 1984, p. 33).

One of the things that like a canker gnaw at the soul of the narrator in solitude and diminish it is this incurable disease. It is because of this disease that he has to be abject, worthless, deprived and isolated and those, the rajaleha, because of their shamelessness and haughtiness and their ability to wear different masks to enjoy all the blessings "I had a feeling that this world was not made for me but for a group of pseudo-intellectuals: a group of shameless, diabolical, rude, beggarish mule-drivers who lack insight and wisdom. It was made for those who were created to suit it, those who, like the hungry dog in front of the butcher shop wagging its tail for a bit of offal, are used to flatter the mighty of the earth and of the sky" (Hedayat, 1984, p. 45). Almost the same feelings and ideas will be uttered somewhere else in the story "But for some reason everything related to the life-style and the joys of others nauseated me. What relationship could exist between the lives of the fools and healthy rabble who were well, who slept well, who performed the sexual act well, who had never felt the wings of death on their face every moment--what relationship could exist between them and one like me who has arrived at the end of his rope and who knows that he will pass away gradually and tragically" (Hedayat, 1984, p. 37).

According to Natel Khanlari (2003, p. 235) Hedayat belonged to a passive and immobilized social class which was condemned to surrender before the movement of the lower social classes or to change its manners and method. This social class had come to the end of its evolvement procedure because of superfluous comfort and was deteriorating. For this reason all the characteristics of a demolishing generation was materialised in Hedayat. He obviously witnessed the cancellation of the titles of Qajar period and the old families were condemned to discolouring and deforming in the newly raised social classes and since Hedayat was not able to face this compulsory evolvement, he was involved in a type of timidity and shyness and passivity. He was suspicious to anyone from the low social classes who was working hard to heighten his/her social position and was taking them as the usurpers of the social positions. 
He hated all those who worked hard to achieve a better life and he used a particular idiom to refer to them. He used to call the Rajaleh, the rabbles.

This feeling toward his countrymen pushes him toward the verge of losing mental equilibrium. His mental imbalance depicts him as an unusual figure among his native people and excludes him, making him to seem an outsider, merely because he suggests foreign ideas resulted from his half European moods (Fardid, 2003, p. 627). Sadegh Hedayat apparently, because of his fascination toward the western historical traditions, had raised his arm against the oriental traditions but he never succeeded to free himself from the grip of oriental family. Thus there was always a binary opposition lived in him (Fardid, 2003, pp. 627-628). In this sense, he is very much like the Orientalist, who judges the East from the West's viewpoint wherein there is a lack of traditional reform in the Orient. Therefore, the East seems to be, in reference to the aforementioned worthy/unworthy duality, unworthy, according to the narrator. He acts as though he were a member of the colonial class and, yet, his suffering, which results, in part, from his never-ending contemplation of two polar opposites -- the existence or non-existence of metaphysics or the ethereal girl representing the pre-Islamic and glorious time of Sassanid era and the present, post-Islamised conditions embodied in the configuration of his wife, or even tradition represented in the people he names rajaleh, religion and modernity-- parallels the suffering of the post-colonial subject who has been exposed to another set of binary opposites: Eastern thought, and its antithesis; Western thought. The narrator cannot find source of comfort in either culture.

\section{Conclusion}

Under circumstances in which Western-oriented ontological discipline was supporting the Western system many Iranian literary modernists, owning to the $19^{\text {th- }}$ and $20^{\text {th }}$-century Western literature, began to use a Self and Other view. Using this conceptual framework, they stand themselves apart from their traditional culture and people and judge them as the Other, symbol of Inferiority (Said, 1978, p. 4).These modernist Iranian writers who have been supposed to act as the consciousness of Iranians and the voice of the victimized people of their own time have fallen prey to westoxification.

Said (1978, p. 7) argues European culture is hegemonic and imparts the idea of a superior European identity to the world. The "East" or "Orient" being the entity of the Islamic countries which are viewed as "inferior." Mashallah Ajoudani (2006, pp.115-126) claims that intelligentsia was influenced by the Western European view of the world as the only correct one. This Intelligentsia including Hedayat found themselves developing a sense of dislocating their feeling of place from Iran to Western countries. This confused sense of identity contributes to an emotional and at large conceptual distance between the mimic man and the others and this led him to reject the cultural traditions of his people and with them, any comfort of traditional religious teachings. Thus we can infer that the main reason for the narrator's irrational and to some extent imbalanced behavior lies in his awareness of the fact that he is cut from his roots which signifies the double consciousness, a way of perceiving the world that is divided between two cultures which produces an unstable sense of self, feeling of being caught between cultures and a sense of unhomeliness, therefore he must look for a superior being which can help him to solve his complexes in him. However, these complexes will end in his isolation and alienation from his native culture, traditions and finally his people whom he has already labeled as Rajaleha, the rabbles.

\section{References}

Al-e Ahmad, J. (1984). Occidentosis: A plague From the West. Trans. R. Campbell. Mizan Press.

Ajoudani, M. (2006). Hedayat, Blind owl and Nationalism. London: Fasl-e Ketab Publications.

Ashcroft B., G. G., \& H. Tiffin (2004). Post-colonial Studies: The Key Concepts. London: Routledge.

Axworthy, M. (2007). Iran Empire of the Mind. London: Penguin Books

Benab, Y. P. (2011). The origin and development of imperialist contention in Iran; 1884-1921 A case study in under development and dependency [Electronic Version], Retrieved March 23, 2011, from www.iranchamber.com/.../origin_development_imperialist_contention_iran4.php

Cole, R. I. J. (1995). Marking Boundaries, Marking Time: The Iranian Past and the Present Construction of the Self by qajar Thinkers. Paper presented at the Middle east Studies association of North America

Etehad, H. (2009). Pejouheshgaran-e Moa'ser Iran (The Iranian Contemporary Researchers) Tehran: Farhang-e Moa'ser.

Fardid, A. (2003). Andeshehhay-eh sadegh Hedayat. In Yad-e sadegh Hedayat (In the Memeory of Sadegh Hedayat) In A. Dehbashi (Ed.), Beyad-e Sdadegh Hedayat (on the memory of Sadegh Hedayat). Tehran: Sales publisher.

Hedayat, S (1957). The Blind Owl. New York: Grove Press 
Hedayat. S (1984). The Blind Owl. Translated by Iraj Bashiri. Retrieved December 10, 2009, from http://www.angelfire.com/rnb/bashiri/Stories/Blind Owl.html

Hedayat, S. (1995). The Dark House USA.

Hedayat, S. (1932). Se qatre khün (Three Drops of Blood) Tehran.

Hedayat, S. (1942). The deadlock In The Stray Dog. Retrived December 12, 2010, from http://www.angelfire.com/rnb/bashiri/Stories/3Drops.html

Hedayat, S. (2000). Three Drops of Blood. Retrived April, 15, 2011, from http://www.angelfire.com/rnb/bashiri/Stories/3Drops.html

Katem, R. (2006). Nationalism in Iran. Translated by Ahmad Tadayon. Tehran: Kavir Publications

Katouzian, M. A. H. (2002). Sadegh Hedayat: the Life and Literature of an Iranian Writer. London: I.B. Tauris \& co Ltd.

Katouzian, M. A. H. (1993). Sadegh Hedayat va Marg-e Nevsandeh (Sadegh Hedayat and the Death of the Author). Tehran: Marklaz Publisher.

Khanlari, P. N. (2003). Khaterat-e Adebi Dar Barehy-e Sadegh Hedayat ( Literary Memory about Sadegh Hedayat). In A. Dehbashi (Ed.), Be Yad-e Sadegh Hedayat (On the memory of Sadegh Hedayat). Tehran: Sales publisher.

Mirabedini, H. (2003). Sadegh Hedayat- Rzenehi be Rahai (Sadegh Hedayat- An Opening to Freedom) In A. Dehbashi (Ed.), Be Yad-e Sadegh Hedayat (On the memory of Sadegh Hedayat). Tehran: Sales publisher.

Nafisi, A. (2003). Mo'azal-e Buf-e Kur (The Dilemma of Buf-e Kur). In A. Dehbashi (Ed.), Be Yad-e Sadegh Hedayat (On the memory of Sadegh Hedayat). Tehran: Sales publisher.

Royle, N. (2000). Deconstructions: A User's Guide. Ebb Vale U. K.; Creative Print and Design.

Said, E. (1978). Orientalism. New York: Pantheon Books. 